\title{
Short-term dynamics of soil aggregate stability in the field
} recherche Val de Loire, CS 40001, F-45075 Orléans Cedex 2, France.

${ }^{2}$ Institut National de la Recherche Agronomique (Inra), UMR1221 LISAH, 2 place Viala, F-34060 Montpellier, France.

\section{Abstract}

10 Aggregate stability is a key property affecting the movement and storage of water, seedling

11 emergence and soil sensitivity to erosion. Many studies have shown that aggregate stability

12 changes through time. Field monitoring studies performed with a relatively large (monthly)

13 time step showed seasonal trend of aggregate stability. But shorter time step monitoring are

14 required to explore dynamics of aggregate stability at short term. For now, biological

15 activity was recognized to be the main factor of aggregate stability dynamic. But previous

16 studies were currently based on the external stimulation of aggregate stability. The

17 objectives of the study were to assess variations in aggregate stability at short time steps in

18 the field and to identify the factors controlling these variations of stability. A six months

19 field monitoring was performed at short time step (two to five days) on a bare field on

\section{Corresponding author \\ Baptiste.Algayer@gmail.com}


20 Luvisol without organic amendment. Aggregate stability was measured for both on surface

21 and subsurface materials by the ISO/DIS 10930 method. Rain amount and intensity, air

22 temperature and humidity, soil temperature, water content and hydric history, soil water

23 repellency were measured as explanatory factors. The results showed that aggregate

24 stability varied greatly (up to $40 \%$ ) over a few days for both surface and subsurface. Short

25 term dynamics of aggregate stability were already shown by laboratory experiments, but

26 such dynamics was never observed in the field for a bare soil without external stimulation

27 of biological activity. For the surface, short time step variations of surface aggregate

28 stability were primarily controlled by soil water content $\left(\mathrm{WC}_{0}\right.$ and $\left.\mathrm{WC}_{1 / 2}\right)$, hydric history

$29\left(\Delta \mathrm{WC}_{4}\right.$ and $\left.\mathrm{API}\right)$ and rain intensity. While large changes in aggregate stability were found

30 for the subsurface, explanatory factors remain to be found.

\section{Introduction}

32 Aggregate stability corresponds to the capacity of a soil aggregate to keep its cohesion

33 and not to break up into smaller fragments when it is submitted to the effect of water. The

34 stability of soil aggregates is a key property since it affects the movement and storage of

35 water, soi aeration, biological activity, seedling emergence, and root penetration (Gallardo-

36 Carrera et al., 2007). It also affects soil sensitivity to erosion and crusting (Le Bissonnais,

37 1996; Bajracharya et al.,1998; Wang et al., 2013).

38 It is well-established that aggregate stability is a time dependent variable (e.g.

39 Bullock et al. 1988; Caron et al., 1992; Bajracharya et al., 1998; Denef et al., 2001). For

40 now, numerous field monitoring studies have identified a seasonal pattern, with the largest

41 aggregate stabilities recorded in summer and the lowest values in winter (Bullock et al.

42 1988; Blackman, 1992; Chan et al. 1994; Dimoyiannis, 2009). Such studies have shown

43 that the temporal variability of the aggregate stability, as measured at monthly time steps

44 over a year, varied between $20 \%$ and $30 \%$, depending upon the study. If seasonal trends of 
45 aggregate stability variation are well identified, there is a lack of knowledge concerning the

46 temporal dynamic of aggregate stability at shorter time step (few days).

47 Laboratory studies performed at short-term explored the mechanisms of aggregate

48 stability variation and the influence of various factors: the biological activity, the wetting

49 and drying cycles, the rain intensity and the freezing-thawing cycles. Such studies showed

50 that aggregate stability increased when the biological activity was stimulated by organic

51 amendment (e.g. Tisdall and Oades, 1982, Le Guillou et al., 2012), underlining that

52 microbial activity has a positive effect on aggregate stability (e.g., Tisdall and Oades,

53 1982; Chenu et al. 2000). Soil temperature affects aggregate stability directly through

54 freezing (Bullock et al. 1988) and indirectly through the stimulation of microbial activity.

55 Rain affects aggregate stability of the soil surface through several processes, including the

56 kinetic energy of raindrop impact and slaking (Shainberg et al., 2003). Soil water content at

57 the time of sampling was found negatively correlated with aggregate stability (Perfect et al.

58 1990; Caron et al., 1992). Soil hydric history affects aggregate stability through physico-

59 chemical processes (Utomo and Dexter, 1982; Kemper and Rosenau, 1984) and through its

60 influence on microbial activity (Denef et al., 2001). Water repellency was shown to affect

61 aggregate stability by decreasing the aggregates wetting rate, limiting the effect of slaking

62 and microcracks formation (Piccolo and Mbagwu, 1999; Cosentino et al. 2006). According

63 to this literature (e.g. Perfect et al. 1990; Blackman 1992; Suwardji and Eberbach, 1998;

64 Denef et al., 2001; Cosentino et al., 2006), temporal dynamics of aggregate stability should

65 be primarily controlled by biological activity. However, such studies have generally been

66 based on either the external stimulation of biological activity by organic amendments

67 (amended soils compared to non-amended soils) (e.g., Cosentino et al., 2006; Abiven et al.,

68 2007; Le Guillou et al., 2012) or the comparison of soils with highly contrasting organic

69 matter contents or management practices (e.g., Blackman 1992; Suwardji and Eberbach, 
70 1998). Thus, there is a lack of information concerning the factors of aggregate stability

71 temporal variation without external stimulation of the biological activity.

72 In the present study, a field monitoring of aggregate stability variations over time steps of a

73 few days was conducted on a bare soil without stimulation of biological activity. The

74 objectives were: 1) to assess how much aggregate stability can vary in the field at short

75 time steps, and 2) to identify the factors controlling the variations of aggregate stability

76 without stimulation of biological activity.

\section{Material and method}

\section{$78 \quad$ Sampling sites}

79 Field monitoring was performed on a site located in the southern part of the Parisian

80 Basin (France), 15 kilometers southwest of the city of Chartres $\left(48^{\circ} 21^{\prime} 5.12^{\prime \prime} \mathrm{N}\right.$;

$\left.811^{\circ} 16^{\prime} 0.55^{\prime} \mathrm{E}\right)$. This site was located on a cultivated field on a typic Luvisol with a gentle

82 slope (7\%) oriented to the north. The field was sown with wheat, and soil was drained by

83 subsurface pipes. The A horizons was a silt loam (Soil Survey Division Staff, 1993), with

$8416 \%$ clay and 2.2\% organic matter. Other soil characteristics are shown in table 1.

\section{Monitoring and sampling setup}

A $50 \mathrm{~m}^{2}$ rectangular plot (12 meter in length and 4 meter in width) was defined within

87 the crop field. The plot was kept bare with herbicide (Bayer jardin, versatile weedkiller, 7

$88 \mathrm{~g} / \mathrm{l}$ glyphosate) during the 6 months of monitoring to facilitate sampling and minimize the

89 effects of vegetation on aggregate stability. The effect of glyphosate on aggregate stability

90 has never been studied according to our knowledge. Monitoring was conducted during six

91 months in 2011. It started just after the seedbed preparation and sowing, on 9 March and it

92 ended on 18 August. 
93 The plot was divided in one-meter-square subplots using plastic sticks. During the

94 monitoring, each subplot was sampled only once. Sampling was carried out at two time

95 scales: a regular monthly time step and at a shorter time step (two to five days) during the

96 two weeks after a significant rain event (Table 2). For each monthly sampling, three

97 distinct samples were collected on non-adjacent subplots from each $50 \mathrm{~m}^{2}$ plot to assess the

98 spatial variability of the measured variables within a plot. During the monitoring, 6 rain

99 events were considered as significant based on their duration, rain amount and maximum

100 intensity. Sampling at shorter time step (2 to 5 days) was performed during the inter-rain

101 periods (Table 2).

102 From a subplot, paired samples of surface and subsurface materials were always

103 collected separately. For the surface samples, material was carefully collected from the top

$1045 \mathrm{~mm}$ using a small spatula. When the soil surface was crusted (Bresson and Boiffin, 105 1990), large pieces (2-to-20 $\mathrm{cm}^{2}$ ) of the crust material were collected using a sharp knife to

106 cut through the crust without affecting its structure. The subsurface material was defined as

107 the material between $1 \mathrm{~cm}$ and $5 \mathrm{~cm}$ below the soil surface. It was carefully collected using

108 a small spade. After May 5, the soil surfaces presented a structural crust, which developed

109 into a sedimentary crust after August 2.

110 For each material (surface and subsurface), samples were divided into 5 subsamples in

111 order to measure aggregate stability, water content at the sampling time, organic matter

112 content, microbial biomass and water repellency. For aggregate stability, samples were

113 dried at $40^{\circ} \mathrm{C}$ during 2 days and stored at $4^{\circ} \mathrm{C}$ before measurement. For organic matter

114 content and microbial biomass, fresh soil samples were sieved at $5 \mathrm{~mm}$ and stored at $4^{\circ} \mathrm{C}$

115 before measurement. For water repellency, fresh samples were stored at $4^{\circ} \mathrm{C}$. 


\section{Measurements}

\section{Aggregate stability}

118 Aggregate stability was measured using a modified version of the ISO/DIS 10930 119 (2012) method which is based on Le Bissonnais (1996). Two tests were considered: fast 120 wetting (FW) and slow wetting (SW). 5 g sub-samples were dried at $40^{\circ} \mathrm{C}$ for $24 \mathrm{~h}$ prior to 121 each test, and each test was replicated three times. Following each stability test, the

122 resulting fragments were sieved in ethanol, and results are presented using the mean 123 weighted diameter of the fragments (MWD) (Le Bissonnais, 1996). The results of each test 124 (hereafter referred as $\mathrm{MWD}_{\mathrm{FW}}$ and $\mathrm{MWD}_{\mathrm{sw}}$ ) were considered separately to analyze the

125 resistance of the material against specific processes (slaking for the fast wetting test and 126 differential clay swelling for the slow wetting test). Each MWD value corresponds to one 127 of five classes of stability: MWD above $2 \mathrm{~mm}$ corresponds to very stable material, 128 between 2 and $1.3 \mathrm{~mm}$ corresponds to stable material, between 1.3 and $0.8 \mathrm{~mm}$ 129 corresponds to median stability, between 0.8 and $0.4 \mathrm{~mm}$ corresponds to unstable material, 130 and lower than 0.4 mm corresponds to very low stability (Le Bissonnais, 1996).

\section{Organic matter content and microbial biomass}

132 As soil was kept bare and no organic amendment was incorporated, biological activity 133 was not expected to change much during the monitoring. Organic matter content and

134 microbial biomass were measured, as control measurements, to characterize the biological 135 activity. Organic matter content was measured using the sulfochromic oxidation method 136 (ISO 14235, 1998), microbial biomass using the fumigation method (ISO 14240-2, 1997). 
137 Potential explanatory variables

138 Air relative humidity and temperature, rain amount and intensity, soil water content and

139 hydric history, and water repellency of the aggregates, were considered as potential

140 explanatory factors of aggregate stability variations.

141 The air relative humidity and temperature were recorded hourly (Vaisala, HMP45C) at $1421.5 \mathrm{~m}$ above ground.

143 Rain amount was measured hourly using a rain gauge (Campbell Scientific, ARG 100).

144 Average rain intensity and maximum rain intensity was calculated for each rain event. To

145 characterize the amount of rainfall in the days preceding a sampling date, an antecedent 146 precipitation index (API) was calculated from the rainfall data using a 7-day duration as:

$147 P_{i}$

where $i$ is the $\mathrm{i}^{\text {th }}$ day before sampling and $P_{i}$ (in $\mathrm{mm}$ ) is the total precipitation height on

149 the $i^{\text {th }}$ day.

150 Soil water content was measured at each sampling time by the gravimetric method

151 carried out on the surface and subsurface samples. Volumetric soil water content and soil

152 temperature were measured hourly using TDR and thermistor probes (Decagon Devices,

153 soil moisture sensor $5 \mathrm{TE})$ at two depths $(1 \mathrm{~cm}$ and $5 \mathrm{~cm})$ and at two different locations in

154 each plot (4 probes per plot) for the whole monitoring duration. According to their design

155 principle, TDR probes are known to show approximate data for very top soils. A

156 preliminary analysis was performed to compare gravimetric water content data and

157 volumetric water content data for the 19 sampling times. Results showed that these

158 measurements were significantly correlated and showed similar results $\left(\mathrm{r}^{2}=0.79\right)$.

159 To characterize the hydric history of the soil, two indices were calculated from the

160 water content data: the mean of water content for a duration $t$ (in days) prior sampling

$161\left(W C_{t}\right)$ and the difference in water content between the beginning and the end of that period 
$162\left(\Delta W C_{t}\right)$. A preliminary analysis based on a correlation analysis was performed to identify

163 the duration of both hydric history indices that was the most relevant to aggregate stability

164 changes. For both indices, durations ranging from 0.25 to 8 days were tested. Results

165 showed that the most-significant durations were half day for water content $\left(W C_{1 / 2}\right)$ and 4

166 days for the difference in water content $\left(\Delta W C_{4}\right)$.

167 Subcritical water repellency was measured with the intrinsic sorptivity method

168 (Tillman et al., 1989). The experimental design described by Hallett and Young (1999) was

169 used. Measurements were performed on 1-cm-diameter aggregates, on surface samples

170 only. Samples were dried at $40^{\circ} \mathrm{C}$ during the $48 \mathrm{~h}$ prior to measurements. When the soil

171 surface was crusted, measurements were made on the top of $1 \mathrm{~cm}^{2}$ crust fragments.

172 Subcritical water repellency was expressed as the water repellency index R defined by

173 Tillman et al. (1989). The given R value corresponds to the mean of 10 replicates. A higher

$174 \mathrm{R}$ value means a larger water repellency. An $\mathrm{R}$ index equal to 1.0 corresponds to a

175 completely non-repellent material, an R index between 1.0 and 1.95 corresponds to a non-

176 repellent material and an $\mathrm{R}$ index higher than 1.95 corresponds to a subcritical water

177 repellent material (Tillman et al., 1989).

\section{Statistical analysis}

179 Statistical analysis were completed using R software version 2.9.2 (R Development

180 Core Team, 2011). The short time step variability was considered as significant when its

181 coefficient of variation (CV) was significantly larger than the CV of the spatial variability

182 measured at the monthly time step. Throughout the whole study, a 5\% significance level

183 was considered. Linear correlation analysis (Pearson's coefficient) were used to identify

184 relationships between the MWD and the other factors. This analysis was carried out for the

185 surface and subsurface datasets separately. In order to classify the identified factors, and to 
186 measure their combined effect on aggregate stability (MWD), simple and multiple

187 regression analysis were carried out.

188 Results

189 Temporal variation of aggregate stability

$190 \quad \mathrm{MWD}_{\mathrm{FW}}$ and $\mathrm{MWD}_{\mathrm{sW}}$ were significantly correlated ( $\mathrm{r}=0.82$, $\mathrm{p}$-value $\left.<0.001\right)$. Because

191 the slow wetting test exhibited the largest temporal dynamics, only this test is detailed in

192 the present section (Figures 1 and 2).

193 Based on the monthly samples, the largest spatial variability of the $\mathrm{MWD}_{\mathrm{sw}}$ at a given 194 time was $9 \%$ for the surface and $12 \%$ for the subsurface (Figure 1a). As it was explained 195 previously, variations above this threshold were considered as significant. During the 196 monitoring period, aggregate stability varied greatly for both the surface and the 197 subsurface. The surface $\mathrm{MWD}_{\mathrm{sw}}$ ranged from $0.34 \mathrm{~mm}$ (very unstable) to $0.99 \mathrm{~mm}$ 198 (medium stability), with a mean of $0.68 \mathrm{~mm}$, a variance of $0.04 \mathrm{~mm}^{2}$ and a CV of $29 \%$. 199 The subsurface $\mathrm{MWD}_{\mathrm{sw}}$ ranged from $0.39 \mathrm{~mm}$ (very unstable) to $1.08 \mathrm{~mm}$ (medium 200 stability), with a mean of $0.60 \mathrm{~mm}$, a variance of $0.04 \mathrm{~mm}^{2}$ and a CV of $32 \%$. Such 201 dynamics in time are considered significant because there are larger than the spatial 202 variability assessed at a given time by the monthly sampling (Figure 1a).

203 Considering the monthly time step only (Figure 1a), the CV of aggregate stability was $20429 \%$ for the surface and 32\% for the subsurface. Considering the short time step, aggregate 205 stability also varied greatly for both surface and subsurface: the same CV were found for 206 both surface and subsurface. Variance of the aggregate stability was similar between the 207 monthly time step and the short time step monitoring ( $\mathrm{p}$-value $=0.8$ for both surface and 208 subsurface).

209 Short time step sampling periods showed various trends in aggregate stability (Figure 210 2). During the May short-time monitoring period (Figure 2a), the variance of surface 
211 MWD $_{\text {sw }}$ was $0.01 \mathrm{~mm}^{2}$ for both surface $(\mathrm{CV}=9 \%)$ and subsurface $(\mathrm{CV}=17 \%)$. The surface

212 MWD $_{\text {sw }}$ decreased significantly immediately after rain 1, but did not changed after R2.

213 Subsurface $\mathrm{MWD}_{\mathrm{sw}}$ did not varied significantly after both rain events. During June short-

214 time monitoring period (Figure $2 \mathrm{~b}$ ), the surface $\mathrm{MWD}_{\mathrm{sw}}$ showed a variance of $0.05 \mathrm{~mm}^{2}$

215 with a CV of $42 \%$, while the subsurface $\mathrm{MWD}_{\mathrm{sw}}$ was much more stable (variance $=0.01$

$216 \mathrm{~mm}^{2}$ and $\mathrm{CV}=15 \%$ ). The surface $\mathrm{MWD}_{\mathrm{sw}}$ decreased significantly after $\mathrm{R} 3$ and $\mathrm{R} 4$,

217 showing its largest decrease after R4: from $0.78 \mathrm{~mm}$ (10 June, prior rainfall 4) to $0.38 \mathrm{~mm}$

218 (14 June). Inter-rain periods 3 and 4 showed a significant increase of the $\mathrm{MWD}_{\mathrm{sw}}$, the

219 largest increase of the $\mathrm{MWD}_{\mathrm{sw}}$ occurring during the inter-rain period 3: from $0.34 \mathrm{~mm}$ (8

220 June) to $0.78 \mathrm{~mm}$ (10 June). During August short-time step monitoring (Figure 2c), the

221 variance of $M_{\text {WW }}$ was $0.02 \mathrm{~mm}^{2}$ for the surface $(\mathrm{CV}=20 \%)$ and $0.05 \mathrm{~mm}^{2}$ for the

222 subsurface $(\mathrm{CV}=30 \%)$. Both surface and subsurface $\mathrm{MWD}_{\mathrm{sw}}$ kept stable after R5 but

223 decreased significantly after R6. Inter-rain periods 5 and 6 showed significant increase of

224 MWD $_{\text {sw }}$ for both surface and subsurface.

\section{Explanatory variables}

226 Results of the temporal dynamics of the explanatory variables are presented in Tables

2273 and 4 and in Figures 3 and 4. Organic matter content varied between 1.8\% and 1.4\% ,

228 with a variance of $0.01 \%^{2}$ and a CV of $6 \%$ for both surface and subsurface (Figure 3a).

229 Microbial biomass showed a larger variability: a variance of 1609 and a CV of 26\% for the

230 surface and a variance of 2767 and a CV of $43 \%$ for the subsurface (Figure 3b).

231 The $\mathrm{R}$ index of the surface was often larger than 1.95, indicating that the samples

232 could present a subcritical hydrophobicity. Water repellency showed a large temporal

233 variability with a CV of 50\% (Table 3, Figure 3c). 
Air temperature varied between $1.6^{\circ} \mathrm{C}$ and $36.1^{\circ} \mathrm{C}$. Air temperature was always

235 positive during the monitoring period, hence no freezing occurred. Soil surface

236 temperature varied between $4.8^{\circ} \mathrm{C}$ and $31.2^{\circ} \mathrm{C}$ with a $\mathrm{CV}$ of $32 \%$, while subsurface

237 temperature varied between $9.7^{\circ} \mathrm{C}$ and $30.4^{\circ} \mathrm{C}$ with a $\mathrm{CV}$ of $19 \%$ (Figure $4 \mathrm{a}$ and $4 \mathrm{~b}$ ). The

238 studied site exhibited a cumulated rain of $219 \mathrm{~mm}$. Among the 6 rain event considered, R3

239 (June 4) presented the highest rain amount (26.2 $\mathrm{mm}$ in 7 hours) and a maximum intensity

240 of $16.8 \mathrm{~mm} \mathrm{~h}^{-1}$ (table 4b). The dynamic of the soil water content was very different between

241 the surface and the subsurface. Surface water content showed a variance of $10.3 \%{ }^{2}$ and a

$242 \mathrm{CV}$ of $28 \%$ while subsurface water content remained very stable (variance $=0.06 \%^{2}$ and

243 CV=4\%) (Table 3c; Figure 4c).

\section{Relationships between aggregate stability and explanatory variables}

245 Aggregate stability did not significantly correlated with microbial biomass, organic 246 matter and water repellency whatever the stability test (Table 5). The same results were 247 found between MWD and air temperature, soil temperature or air humidity (not shown).

248 A correlation analysis was performed to test the influence of the rain characteristic on 249 aggregate stability. For the 6 considered rain events, correlation coefficient were calculated 250 between rain amount, mean intensity and maximum intensity, and the MWD value 251 measured immediately after the rain event. The best correlation coefficient was found 252 between the maximum intensity of the rain event and the surface MWD measured 253 immediately after the rain event ( $r=-0.77$ for $\mathrm{MWD}_{\mathrm{FW}}$ and -0.83 for $\mathrm{MWD}_{\mathrm{sW}}$ ). Mean rain

254 intensity and total rain amount did not correlate significantly with aggregate stability. 255 Subsurface MWD did not correlate with rain event characteristics. The same analysis was 256 performed between rain characteristics and the difference between MWD before and after 257 the rain event. Here also, the best correlation coefficient was found between the maximum 258 intensity of the rain event and the difference between MWD before and after the rain event 
259 ( $\mathrm{r}=0.82$ for $\mathrm{MWD}_{\mathrm{FW}}$ and 0.80 for $\mathrm{MWD}_{\mathrm{sw}}$ ). Considering the soil water content and hydric

260 history, for the surface, the MWD was significantly and negatively correlated with the

$261 \mathrm{WC}_{0}, \mathrm{WC}_{1 / 2}, \Delta \mathrm{WC}_{4}$ and API for both stability tests (Table 6). For the subsurface, no

262 significant correlation were found between any of the MWD and the variables linked to

263 hydric history (API, $\mathrm{WC}_{0}, \mathrm{WC}_{1 / 2}$ and $\Delta \mathrm{WC}_{4}$ ), except for the $\mathrm{MWD}_{\mathrm{sw}}$ that significantly and

264 negatively correlated with $\mathrm{WC}_{0}(\mathrm{r}=-0.57)$ (table 6).

265 In order to classify the influence of each variable found to be significantly correlated

266 with aggregate stability, and to measure the combined effect of these variables, regression

267 analysis were done. The considered variables were: $\mathrm{WC}_{0}, \mathrm{WC}_{1 / 2}, \mathrm{API}$ and $\Delta \mathrm{WC}_{4}$ for the

268 surface, and $\mathrm{WC}_{0}$ for the subsurface. At first, simple regression analysis was conducted

269 (Table 7). For the subsurface, none of the simple regression models were significant,

270 regardless of the aggregate stability test. Considering the surface $\mathrm{MWD}_{\mathrm{FW}}$, the best simple

271 regression model was with $\mathrm{WC}_{1 / 2}\left(54 \%\right.$ of $\mathrm{MWD}_{\mathrm{FW}}$ variation). Models with $\mathrm{WC}_{0}$ or $\mathrm{API}$

272 were also statistically significant ( $r^{2}=51 \%$ and $37 \%$, respectively). For the slow wetting

273 test, all four models were significant, with $\mathrm{r}^{2}$ between $39 \%$ and $50 \%$ (Table 7). The

274 variables found to be significant during this simple regression analysis were combined in

275 multiple regression models (except $\mathrm{WC}_{0}, \mathrm{WC}_{1 / 2}$, and API, which were not independent).

276 Among all combinations, the only valid multiple regression models were found for the

277 surface. $\mathrm{WC}_{1 / 2}$ and $\Delta \mathrm{WC}_{4}$ together accounted for $59 \%$ of the $\mathrm{MWD}_{\mathrm{sw}}$, and the combination

278 of $\mathrm{WC}_{0}$ and $\Delta \mathrm{WC}_{4}$ accounted for $57 \%$ of the $\mathrm{MWD}_{\mathrm{sW}}$.

279 Discussion

280 Aggregate stability varied significantly at short time step

281 The results show that the aggregate stability in the field varied greatly at short time 282 steps (of a few days). Variations up to 32\% were measured for both surface and subsurface 283 materials. Short term dynamics of aggregate stability was already observed during 
284 laboratory experiments (e.g. Utomo and Dexter, 1982; Denef et al., 2001; Cosentino et al., 285 2006), but, according to our knowledge, only one study observed it in the field (Caron et 286 al., 1992). Moreover, the variability of aggregate stability was never observed by field 287 measurements for a bare soil without any external stimulation of biological activity.

288 Up to now, most field monitoring studies used monthly samplings to assess aggregate 289 stability dynamics (Blackman, 1992; Bajracharya et al., 1998; Suwardji and Eberbach, 290 1998; Dimoyiannis, 2009). Such studies showed that during the year, aggregate stability 291 could vary between $20 \%$ up to $30 \%$. The present study showed that same variability of 292 aggregate stability was occurring at a much smaller time scale. Moreover, for specific 293 periods, aggregate stability can show a larger variability at short time step than at monthly 294 time step. It was the case for the June monitoring period when surface aggregate stability 295 varied up to $46 \%$ over a 7-day period, proving that large changes in aggregate stability are occurring over a few days. In some cases, variations in aggregate stability at short time steps induced changes of up to two stability classes. Such large changes would affect soil properties, such as storage of water, root penetration (Gallardo-Carrera et al., 2007) or soil sensitivity to erosion (Le Bissonnais, 1996; Bajracharya et al.,1998; Wang et al., 2013), and 300 thus, should not be ignored by future studies.

301 Considering this short term dynamics, it appears clearly that monthly measurements 302 are not enough to assess precisely the temporal dynamic of aggregate stability. Monthly 303 time step monitoring give information on the dynamics of aggregate stability at the 304 seasonal scale, but monthly estimation of aggregate stability cannot be used as actual 305 values of aggregate stability at a given time. Short time step measurements are required to reach accurate assessments of aggregate stability. 
In the present study, soil was kept bare during all the monitoring, and no amendments

310 were incorporated. Aggregate stability did not significantly correlated with organic matter

311 content nor microbial biomass, for both surface and subsurface. This result leads us to

312 conclude that a stimulation of biologic activity (i.e. organic amendment) is required to

313 make it affect aggregate stability.

314 Water repellency of the surface aggregates varied independently from the aggregate

315 stability. Based on previous studies (Piccolo and Mbagwu, 1999; Cosentino et al., 2006;

316 Goebel et al., 2012) this variable was expected to influence aggregate stability. In our case,

317 the range of measured $\mathrm{R}$ index (between 1.9 and 7.0) did not correspond to very contrasted

318 water repellencies. It seeems that more contrasted water repellencies are required to

319 influence aggregate stability.

320 The result of the present study underlined the significant influence of rain events on

321 surface aggregate stability dynamics. Aggregate stability decreased significantly after 4 of

322 the 6 rain events. The largest decrease was observed for the rain 4 which showed the

323 highest total rain amount and maximum rain intensity. According to the results of the

324 correlation analysis, the maximum rain intensity appeared to be the dominant factor of

325 aggregate stability decrease upon all the considered rain characteristics. The greater the

326 maximum rain intensity, the greater the aggregate stability decrease. Relationships between

327 rain amount and aggregate stability were observed in the field by monthly monitoring

328 studies (Blackman, 1992; Bajracharya et al., 1998; Suwardji and Eberbach, 1998;

329 Dimoyiannis, 2009). Usually, temporal patterns of precipitation are considered as an

330 important factor in aggregate stability decrease through raindrop impact, which affects the

331 structure of surface aggregates, and through the increase of soil water content (e.g.

332 Shainberg et al., 2003; Dimoyiannis, 2009). The present study underlines the importance of

333 rain intensity on the short time step aggregate stability decrease. More than the rain 
334 amount, the maximum rain intensity seems to be a dominant indicator of surface aggregate

335 stability decrease. However, as only six rain events were considered, such result must be

336 taken carefully, and more detail studies should be conducted to confirm this observation.

337 Subsurface aggregate stability was not related to rainfall characteristics

338 The results also showed that the soil water content and its dynamics were dominant

339 factors of surface aggregate stability. Soil water content at the time of sampling $\left(\mathrm{WC}_{0}\right)$ and

340 few hours before sampling ( $\left.\mathrm{WC}_{1 / 2}\right)$ were significantly and negatively correlated with

341 aggregate stability. Simple regression models with $\mathrm{WC}_{0}$ explained up to $51 \%$ of aggregate

342 stability variation $\left(\mathrm{MWD}_{\mathrm{FW}}\right)$, while simple regression models that included $\mathrm{WC}_{1 / 2}$

343 explained up to $54 \%$ of the aggregate stability variations ( $\mathrm{MWD}_{\mathrm{FW}}$ ), making $\mathrm{WC}_{1 / 2}$ the

344 dominant explanatory factor in aggregate stability variation at short time step.

345 Previous studies (e.g., Perfect et al., 1990; Blackman, 1992; Dymoyiannis, 2009) have

346 found negative correlations between water content and aggregate stability variation at the

347 monthly time step. The present study found similar relationships at a short time step (a few

348 days) but for surface aggregate stability only. In a field monitoring study performed at

349 short time step (2 days) on a bare soil, Caron et al. (1992) did not found significant

350 relationships between aggregate stability and $\mathrm{WC}_{0}$. In this previous study, samplings were

351 performed within the plowed layer (between -15 and $-25 \mathrm{~cm}$ ). Similarly, the present study

352 did not a relationship between aggregate stability and $\mathrm{WC}_{0}$ for the plowed layer $(-1$ to -5

$353 \mathrm{~cm})$. Such a relationship was found only for the soil surface $(0$ to $-0.5 \mathrm{~cm})$.

354 The soil hydric history indices $\Delta \mathrm{WC}_{4}$ and API were found to be significant factors of

355 surface aggregate stability and were negatively correlated with aggregate stability for the

356 soil surface. The relationship between the water content history and aggregate stability give

357 two pieces of information. Firstly, aggregate stability decreases when the soil is getting

358 more humid: the greater the wetting, the larger the decrease of aggregate stability. This 
359 result confirms the negative influence of rain amount and intensity on aggregate stability

360 that we previously observed. A high rain intensity provokes a rapid soil wetting with a

361 large wetting amplitude that decreases aggregate stability (e.g. R3), while a rain event with

362 a low rain intensity and thus a wetting with a small amplitude do not affect aggregate

363 stability (e.g. R5). Secondly, aggregate stability increases when the soil is drying, and the

364 more intense the drying, the larger the increase of aggregate stability: a large amplitude

365 drying caused an increase in aggregate stability as it was the case during IR 3 and 6, while

366 a small drying amplitude did not affect aggregate stability as for IR 1 and 2.

367 These results were previously observed by laboratory studies. They showed wetting

368 cause a decrease of aggregate stability through physico-chemical processes such as the loss

369 of inter-particle cohesion (Sheel et al., 2008), slaking (Zaher et al., 2005) and microcraking

370 (Le Bissonnais, 1996). They also showed that drying increases aggregate stability by the

371 formation of bonds between particles in relationship with clay flocculation and

372 precipitation of soluble components (Kemper and Rosenau, 1984; Kemper et al., 1987;

373 Dexter et al., 1988). While these relationships were only observed in laboratory

374 experiments, the present study clearly observed similar relationships for field conditions,

375 suggesting the same processes may be active.

376 Conclusions

377 Aggregate stability varied greatly over time steps of a few days for both surface and 378 subsurface. Short term dynamics of aggregate stability were already shown by laboratory 379 experiments, but such dynamics was never observed in the field for a bare soil without 380 external stimulation of biological activity (i.e. no organic amendment). MWD variations of 381 up to $42 \%$ were measured at short time step for specific periods proving that large changes 382 in aggregate stability are occurring even in a few days. Such large changes are likely to 383 affect soil properties such as storage of water and soil sensitivity to erosion, and thus, 
384 should not be ignored. At the surface, short time step variations of aggregate stability were

385 primarily related with water: Rain maximum intensity, water content at or close to the time

386 of sampling ( $\mathrm{WC}_{0}$ and $\mathrm{WC}_{1 / 2}$ ), and hydric history indices $\left(\Delta \mathrm{WC}_{4}\right.$ and $\mathrm{API}$ ) were the

387 dominant factors influencing surface aggregate stability. While large changes in aggregate

388 stability were found for the subsurface, explanatory factors remain to be found. These

389 results underline the dominant effect of abiotic factors such as water content dynamics on

390 aggregate stability variations at a short time step in the field in the absence of biological

391 activity stimulation. To improve the prediction of aggregate stability, further research

392 should analyze the interactions between abiotic and biotic factors at short time step in the

393 field. 


\section{References}

396 Abiven S., S. Menasseri, D. A. Angers and P. Leterme. 2007. Dynamics of aggregate 397 stability and biological binding agents during decomposition of organic materials. Eur. J. Soil Sci. 58:239-247.

Bajracharya R. M., R. Lal, and G. F. Hall. 1998. Temporal variation in properties of an 400 uncropped, ploughed Miamian soil in relation to seasonal erodibility. Hydr. Proc. $12: 1021-1030$.

Bullock M. S., W. D. Kemper and S. D. Nelson. 1988. Soil cohesion as affected by freezing, water content, time and tillage. Soil Sci. Soc. Am. J., 52:770-776.

405

Blackman, J. D. 1992. Seasonal variation in the aggregate stability of downland soils. Soil Use and Management. 8:142-150.

Bresson L. and J. Boiffin. 1990. Morphological characterization of soil crust development stages on an experimental field. Geoderma. 47:301-325.

408 Caron J., B. D. Kay, J. A. Stone and R. G. Kachanoski. 1992. Modelling temporal changes 409 in structural stability of a clay loam soil. Soil Sci. Soc. Am. J. 56:1597-1604.

410 Chan, K. Y., D. P. Heenan and R. Ashley. 1994. Seasonal changes in surface aggregate 411 stability under different tillage and crops. Soil \& Till. Res. 28:301-314.

412 Chenu C., Y. Le Bissonnais and D. Arrouays. 2000. Organic matter influence on clay $413 \quad$ wettability and soil aggregate stability. Soil Sci. Soc. Am. J. 64:1479-1486.

414 Cosentino D., C. Chenu and Y. Le Bissonnais. 2006. Aggregate stability and microbial 415 community dynamics under drying-wetting cycles in a silt loam soil. Soil Bio. and Biochem. 38:2053-2062.

417 Denef K., J. Six, H. Bossuyt, S. D. Frey, E. T. Elliott, R. Merckx and K. Paustian. 2001. 418 Influence of wet-dry cycles on the interrelationship between aggregates, particulate 
419 organic matter and microbial community dynamics. Soil Bio. \& Biochem. 33:1599$420 \quad 1611$.

421 Dexter A. R., R. Horn and W. D. Kemper. 1988. Two mechanisms for age-hardening of 422 soil. J. Soil Sci. 39:163-175.

423 Dimoyiannis D. 2009. Seasonal soil aggregate stability variation in relation to rainfall and 424 temperature under Mediterranean conditions. Earth Surf. Proc. Land. 34:860-866.

425 Gallardo-Carrera A., J. Léonard, Y. Duval and C. Dürr. 2007. Effects of seedbed structure 426 and water content at sowing on the development of soil surface crusting under rainfall. $427 \quad$ Soil \& Till. Res. 95:207-217.

428 Goebel M. O., S. K. Woche and J. Bachmann. 2012. Quantitative analysis of liquid 429 penetration kinetics and slaking of aggregates as related to solid-liquid interfacial 430 properties. J. of Hydr. 442:63-74.

431 Hallett P. D. and I. M. Young. 1999. Changes to water repellence of soil aggregates caused 432 by substrate-induced microbial activity. Eur. J. Soil Sci. 50:35-40.

433 ISO/DIS 10930. 2012. Soil quality - Measurement of the stability of soil aggregates 434 subjected to the action of water. International Organization for Standardization, 435 Geneva, Switzerland.

436 Kemper W. D. and R. C. Rosenau. 1984. Soil cohesion as affected by time and water 437 content. Soil Sci. Soc. Am. J. 48:1001-1006.

438 Kemper W. D., R. C. Rosenau and A. R. Dexter. 1987. Cohesion development in disrupted 439 soils as affected by clay and organic matter content and temperature $440 \quad$ Soil Sci. Soc. Am. J. 51:860-867.

441 Le Bissonnais Y. 1996. Aggregate stability and assessment of soil crustability and 442 erodibility: I. Theory and methodology. Eur. J. Soil Sci. 47:425-437. 
443 Le Guillou C., D. A. Angers, P. A. Maron, P. Leterme and S. Menasseri-Aubry. 2012. 444 Linking microbial community to soil water-stable aggregation during crop residue 445 decomposition. Soil Bio. \& Biochem. 50:126-133.

446 Perfect E., B. D. Kay, W. K. P. Van Loon, R. W. Sheard and T. Pojasok. 1990. Rates of 447 change in soil structural stability under forages and corn. Soil Sci. Soc. Am. J. 54:179$448 \quad 186$.

449 Piccolo A. and J. S. C. Mbagwu. 1999. Role of hydrophobic components of soil organic matter on aggregate stability. Soil Sci. Soc. Am. J. 63:1801-1810.

451 R Development Core Team. 2011 R: A Language and Environment for Statistical Computing. R Foundation for Statistical Computing. At: http://www.R-project.org

Shainberg I., A. I. Mamedov and G. J. Levy. 2003. Role of wetting rate and rain energy in seal formation and erosion. Soil Sci. 168:54-62.

Sheel M., R. Seeman, M. Brinkmann, M. D. Michiel, A. Sheppard, B. Breidenbach and S. Herminghaus. 2008. Morphological clues to wet granular pile stability Nat. materials. 2117:1-5.

Soil Survey Division Staff. 1993. Soil Survey Manual. Soil Conservation Service. United State Department of Agriculture.

Handbook

18. At: http://soils.usda.gov/technical/manual/

461 Suwardji P. and P. Eberbach. 1998. Seasonal changes of physical properties of an Oxic Paleustalf (Red Kandosol) after 16 years of direct drilling or conventional cultivation. Soil \& Til. Res. 49:65-77.

464 Tillman J. M., D. R. Scotter, M. G. Wallis and B.E. Clothier B. E. 1989. Water-repellency 465 and its measurement by using intrinsic sorptivity. Aust. J. Soil Res. 27:637-644.

466 Tisdall J. M. and J. M. Oades. 1982. Organic matter and water stable aggregate in soils. J. Soil Sci. 33:141-163. 
Version définitive du manuscrit publié dans / Final version of the manuscript published in:

Soil Science Society of America Journal, 2014, 78(4), 1168-

http://dx.doi.org/10.2136/sssaj2014.01.0009

468 Utomo W. H. and A. R. Dexter. 1982. Changes in soil aggregate water stability induced by

469 wetting and drying cycles in non-saturated soil. Jour. Soil Sci. 33:623-637.

470 Wang, B., F. Zheng, F. Darboux and M. J. M. Römkens. 2013. Soil erodibility for water

471 erosion. A perspective and Chinese experience. Geomorphology, 187:1-10.

472 Zaher H., J. Caron and B. Ouaki. 2005. Modeling aggregate internal pressure evolution

473 following immersion to quantify mechanisms of structural stability. Soil Sci. Soc. Am.

$474 \quad$ J. 69:1-12. 


\section{Figure caption}

476 Figure 1: Temporal variation of aggregate stability for the slow wetting test of surface and

477 subsurface at montly time step (a) and short time step (b).

478 MWD $_{\text {sw }}$ monthly time step: each $\mathrm{MWD}_{\text {sw }}$ point corresponds on the mean of three samples

479 located on the same plot (spatial variability) and 3 replicates for each measurements $(n=9)$.

480 Bars are standard errors.

481 MWD short time step: each MWD corresponds on the mean of three replicates $(n=3)$. Bars

482 are standard error.s

483 Stable, Medium, Unstable, Very unstable, refers to the aggregate stability classes (Le

484 Bissonnais, 1996)

485 Figure 2: Temporal variation of aggregate stability for the slow wetting test at short time

486 step for (a) May , (b) June and (c) August.

487 MWD monthly time step: each MWD corresponds on the mean of three samples located on

488 the same plot (spatial variability) and 3 replicates for each measurements $(n=9)$. Bars are

489 standard errors.

490 MWD short time step: each MWD corresponds on the mean of three replicates $(n=3)$. Bars

491 are standard errors.

492 R1, R2, R3, R4, R5, and R6 refer to the number of the rain event.

493 Figure 3: Temporal variation in (a) organic matter content, (b) microbial biomass and (c)

494 water repellency.

495 a and b: each point is the mean of three replicates; bars are standard errors.

496 c: each point is the mean of 10 replicates; bars are standard errors.

497 Figure 4: Temporal dynamics of the soil variables; a) Surface soil temperature, b) 498 subsurface soil temperature, c) Volumic soil water content for surface and subsurface. 
Version définitive du manuscrit publié dans / Final version of the manuscript published in: Soil Science Society of America Journal, 2014, 78(4), 1168-

499 Curves are to the mean of two replicates

500 
Version définitive du manuscrit publié dans / Final version of the manuscript published in:

Soil Science Society of America Journal, 2014, 78(4), 1168-

http://dx.doi.org/10.2136/sssaj2014.01.0009

501

Table 1: Soil properties for the studied site

\section{Culture}

(current/

\begin{tabular}{rrrrrrrrrrrr} 
antecedent) & Clay & Silt & Sand & $\begin{array}{c}\text { Organic } \\
\text { matter }\end{array}$ & CEC & pH & Ca & Mg & K & Na \\
\hline & $\mathrm{g} \mathrm{kg}^{-1}$ & & & $\mathrm{cmol} \mathrm{kg}^{-1}$ & & - & $\mathrm{g} \mathrm{kg}^{-1}$ & - \\
Wheat/Maize & 164 & 798 & 38 & 21.6 & 9.1 & 6.7 & 8.8 & 0.5 & 0.6 & 0.03 \\
\hline
\end{tabular}


Version définitive du manuscrit publié dans / Final version of the manuscript published in: Soil Science Society of America Journal, 2014, 78(4), 1168- 
Version définitive du manuscrit publié dans / Final version of the manuscript published in:

Soil Science Society of America Journal, 2014, 78(4), 1168-

\section{Sampling}

\begin{tabular}{|c|c|c|c|}
\hline Date & Monthly & Short term & Rain event \\
\hline $16 / 3$ & S0 & & \\
\hline $30 / 3$ & S1 & & \\
\hline $28 / 4$ & S2 & & \\
\hline $2 / 5$ & & & $\mathrm{R} 1$ \\
\hline $3 / 5$ & & S3 & Inter-rain \\
\hline $5 / 5$ & & S4 & period 1 \\
\hline $7 / 5$ & & & $\mathrm{R} 2$ \\
\hline $9 / 5$ & & S5 & \\
\hline $11 / 5$ & & S6 & \\
\hline $13 / 5$ & & S7 & Inter-rain \\
\hline $16 / 5$ & & S8 & period 2 \\
\hline $18 / 5$ & & S9 & \\
\hline $30 / 5$ & S10 & & \\
\hline $4 / 6$ & & & R3 \\
\hline $7 / 6$ & & S11 & \\
\hline $8 / 6$ & & S12 & $\begin{array}{l}\text { Inter-rain } \\
\text { period } 3\end{array}$ \\
\hline $10 / 6$ & & S13 & \\
\hline $14 / 6$ & & S14 & R4 \\
\hline $16 / 6$ & & S15 & \\
\hline $4 / 7$ & S16 & & period 4 \\
\hline $2 / 8$ & S17 & & \\
\hline $4 / 8$ & & & R5 \\
\hline $8 / 8$ & & S18 & \\
\hline $10 / 8$ & & S19 & period 5 \\
\hline $12 / 8$ & & S20 & \\
\hline $14 / 8$ & & & R6 \\
\hline $16 / 8$ & & S21 & Inter-rain \\
\hline $18 / 8$ & & $\mathrm{~S} 22$ & period 6 \\
\hline
\end{tabular}

$504 \mathrm{~S}=$ sampling; $\mathrm{R}$ = rain event

505 
Version définitive du manuscrit publié dans / Final version of the manuscript published in:

Soil Science Society of America Journal, 2014, 78(4), 1168-

http://dx.doi.org/10.2136/sssaj2014.01.0009

506

507 Table 3: variability of the organic matter content, microbial biomass and water repellency

508 of aggregates

\begin{tabular}{|c|c|c|c|c|c|c|c|c|c|c|c|c|c|}
\hline \multicolumn{14}{|c|}{$\begin{array}{cc} & \text { Micro } \\
\text { Organi } & \text { bial } \\
\text { C } & \text { biomas }\end{array}$} \\
\hline \multirow[t]{3}{*}{ matter } & $\mathbf{S}$ & \multicolumn{12}{|c|}{ Water repellency } \\
\hline & & Max & Min & Mean & $\mathrm{CV}$ & Max & Min & Mean & $\mathrm{CV}$ & Max & Min & Mean & $\mathrm{CV}$ \\
\hline & $\%$ & - & & $\mathrm{mg}$ & $\mathrm{kg}^{-1}$ & E & $\%$ & & $\begin{array}{r}\mathrm{F} \\
\text {-ind } \\
\end{array}$ & $\mathrm{X}$ & $\overline{-}$ & $\%$ & \\
\hline & rface & 1.8 & 1.4 & 1.7 & 6 & 234 & 72 & 147 & 26 & 7.4 & 1.2 & 3.3 & 50 \\
\hline Subs & rface & 1.8 & 1.5 & 1.7 & 7 & 256 & 37 & 117 & 46 & & & & \\
\hline
\end{tabular}


Version définitive du manuscrit publié dans / Final version of the manuscript published in:

Soil Science Society of America Journal, 2014, 78(4), 1168-

510

511 Table 4: variability of the a) atmospheric variables: air temperature (Air T), air humidity

512 (Air H) and cumulated rain, b) rain event characteristics, and c) soil variables: soil

513 temperature (Soil T) and soil water content (Soil WC) for the whole monitoring duration.

514 a)

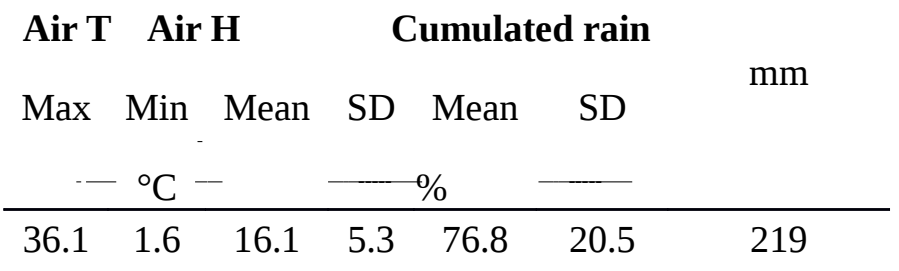

515

516 b)

\begin{tabular}{|c|c|c|c|c|}
\hline & & Duration & $\begin{array}{c}\text { Rain } \\
\text { amount }\end{array}$ & $\begin{array}{c}\text { Maximum } \\
\text { intensity }\end{array}$ \\
\hline Rain event & Date & $\mathrm{h}$ & $\mathrm{mm}$ & $\mathrm{mm} \mathrm{h}^{-1}$ \\
\hline $\mathrm{R} 1$ & $2 / 5$ & 5 & 4.0 & 2.0 \\
\hline $\mathrm{R} 2$ & $7 / 5$ & 3 & 13.2 & 7.0 \\
\hline R3 & $4 / 6$ & 7 & 26.2 & 16.8 \\
\hline R4 & $14 / 6$ & 1 & 9.8 & 9.8 \\
\hline R5 & $4 / 8$ & 8 & 13.5 & 4.0 \\
\hline R6 & $14 / 8$ & 5 & 7.4 & 4.8 \\
\hline
\end{tabular}

517

518 c)

\begin{tabular}{|c|c|c|c|c|c|c|c|c|}
\hline \multirow[t]{2}{*}{ Soil T } & \multicolumn{8}{|c|}{ Soil WC } \\
\hline & Max & Min & Mean & $\mathrm{CV}$ & Max & Min & Mean & $\mathrm{CV}$ \\
\hline & ${ }^{\circ} \mathrm{C}$ & & $\%$ & & $\%$ & & & \\
\hline surface & 31.2 & 4.8 & 19.1 & 32 & 22.5 & 6.1 & 11.7 & 28 \\
\hline subsurface & 30.4 & 9.7 & 18.9 & 19 & 22.8 & 17.9 & 19.6 & 4 \\
\hline
\end{tabular}


Version définitive du manuscrit publié dans / Final version of the manuscript published in:

Soil Science Society of America Journal, 2014, 78(4), 1168-

520 Table 5: correlations (Pearson’s coefficient) between aggregate stability and organic matter

521 content, microbial biomass and water repellency.

\begin{tabular}{llllll} 
& \multicolumn{2}{c}{ Surface } & \multicolumn{3}{c}{ Subsurface } \\
\cline { 2 - 5 } & OM & BIOMI & WR & OM & BIOMI \\
\hline MWD $_{\text {FW }}$ & 0.33 (ns) & $0.25(\mathrm{~ns})$ & $0.12(\mathrm{~ns})$ & $0.34(\mathrm{~ns})$ & $-0.07(\mathrm{~ns})$ \\
$\mathbf{M W D}_{\mathrm{sw}}$ & $0.14(\mathrm{~ns})$ & $0.32(\mathrm{~ns})$ & $0.24(\mathrm{~ns})$ & $-0.29(\mathrm{~ns})$ & $-0.06(\mathrm{~ns})$ \\
\hline
\end{tabular}

522 dataset: $n=19 ; \mathrm{df}=17 ; \alpha=5 \% ; r=0.46$

523 ns=Not significant at the 5\% level

$524 \mathrm{OM}=$ organic matter content

525 BIOMI = microbial biomass

526 WR=water repellency 
Version définitive du manuscrit publié dans / Final version of the manuscript published in:

Soil Science Society of America Journal, 2014, 78(4), 1168-

527 Table 6: Correlations (Pearson’s coefficient) between MWD and soil water indices

\begin{tabular}{|c|c|c|c|c|c|c|c|c|}
\hline & \multirow{2}{*}{$\begin{array}{c}\text { Surface } \\
\qquad W C_{0}\end{array}$} & \multicolumn{7}{|c|}{ Subsurface } \\
\hline & & $W C_{1 / 2}$ & $\Delta W C_{4}$ & $A P I$ & $W C_{0}$ & $W C_{1 / 2}$ & $\Delta W C_{4}$ & $A P I$ \\
\hline $\mathrm{MWD}_{\mathrm{FW}}$ & $\begin{array}{l}-0.73^{*} \\
\end{array}$ & $-0.76^{*}$ & $-0.54 *$ & $-0.63 *$ & $0.14(\mathrm{~ns})$ & 0.13 (ns) & 0.25 (ns) & $-0.18(n s)$ \\
\hline $\mathrm{MWD}_{\mathrm{sW}}$ & $-0.69 *$ & $-0.72 *$ & $-0.70 *$ & $-0.65 *$ & $-0.57^{*}$ & $-0.37(\mathrm{~ns})$ & $-0.04(\mathrm{~ns})$ & -0.25 (ns) \\
\hline
\end{tabular}

528

529 dataset: $n=19 ; \mathrm{df}=17 ; \alpha=5 \% ; r=0.46$

$530 *$ significant at the $5 \%$ level

531 ns = not significant at the $5 \%$ level

$532 \mathrm{WC}_{0}$ : soil water content at the time of sampling

$533 \mathrm{WC}_{1 / 2}$ : mean soil water content for half a day prior to sampling

$534 \Delta \mathrm{WC}_{4}$ : difference between water content at the time of sampling at water content 4 days

535 prior to sampling

536 API: antecedent precipitation index 
Version définitive du manuscrit publié dans / Final version of the manuscript published in:

Soil Science Society of America Journal, 2014, 78(4), 1168-

\begin{tabular}{|c|c|c|c|c|c|c|c|c|c|c|}
\hline \multirow{3}{*}{$\begin{array}{l}\text { Dataset Df } \\
\text { s } \\
\text { Surface }\end{array}$} & \multirow{3}{*}{$\begin{array}{c}\mathbf{W C}_{1 / 2} \\
\mathbf{R}^{2} \\
\mathbf{F W}\end{array}$} & \multirow{2}{*}{$\begin{array}{l}\text { API } \\
\text { level }\end{array}$} & \multicolumn{8}{|c|}{$\Delta \mathrm{WC}_{4}$} \\
\hline & & & \multirow{2}{*}{$\begin{array}{r}\mathbf{R}^{2} \\
0.51\end{array}$} & \multirow{2}{*}{$\begin{array}{l}\text { level } \\
* *\end{array}$} & \multirow{2}{*}{$\begin{array}{r}\mathbf{R}^{2} \\
0.54\end{array}$} & \multicolumn{2}{|c|}{ level } & \multirow{2}{*}{$\begin{aligned} & \mathbf{R}^{2} \\
& \\
& *\end{aligned}$} & \multicolumn{2}{|c|}{ level } \\
\hline & & 17 & & & & $* *$ & 0.37 & & 0.25 &. \\
\hline & SW & 17 & 0.44 & $*$ & 0.50 & $* *$ & 0.39 & $*$ & 0.47 & $* *$ \\
\hline \multirow[t]{2}{*}{ Subsurface } & FW & 17 & 0 & ns & 0 & ns & 0 & ns & 0.01 & ns \\
\hline & SW & 17 & 0.23 & . & 0.29 & . & 0.07 & ns & 0 & ns \\
\hline
\end{tabular}

$540 \mathrm{Df}=$ degrees of freedom; $\mathrm{R}^{2}=$ adjusted coefficient of determination

$541 \quad$ FW: Fast wetting test. SW: Slow wetting test.

$542 \quad * *$ Model significant at the $1 \%$ level

$543 \quad *$ Model significant at the $5 \%$ level

544 . Model significant at the $10 \%$ level

545 ns Model not significant at the $10 \%$ level

$546 \quad \mathrm{WC}_{0}$ : soil water content at the time of sampling

$547 \quad \mathrm{WC}_{1 / 2}$ : average soil water content half a day prior to sampling

$548 \Delta \mathrm{WC}_{4}$ : difference between soil water content at the time of sampling and soil water

549 content four days before

550 API: antecedent precipitation index 
Version définitive du manuscrit publié dans / Final version of the manuscript published in:
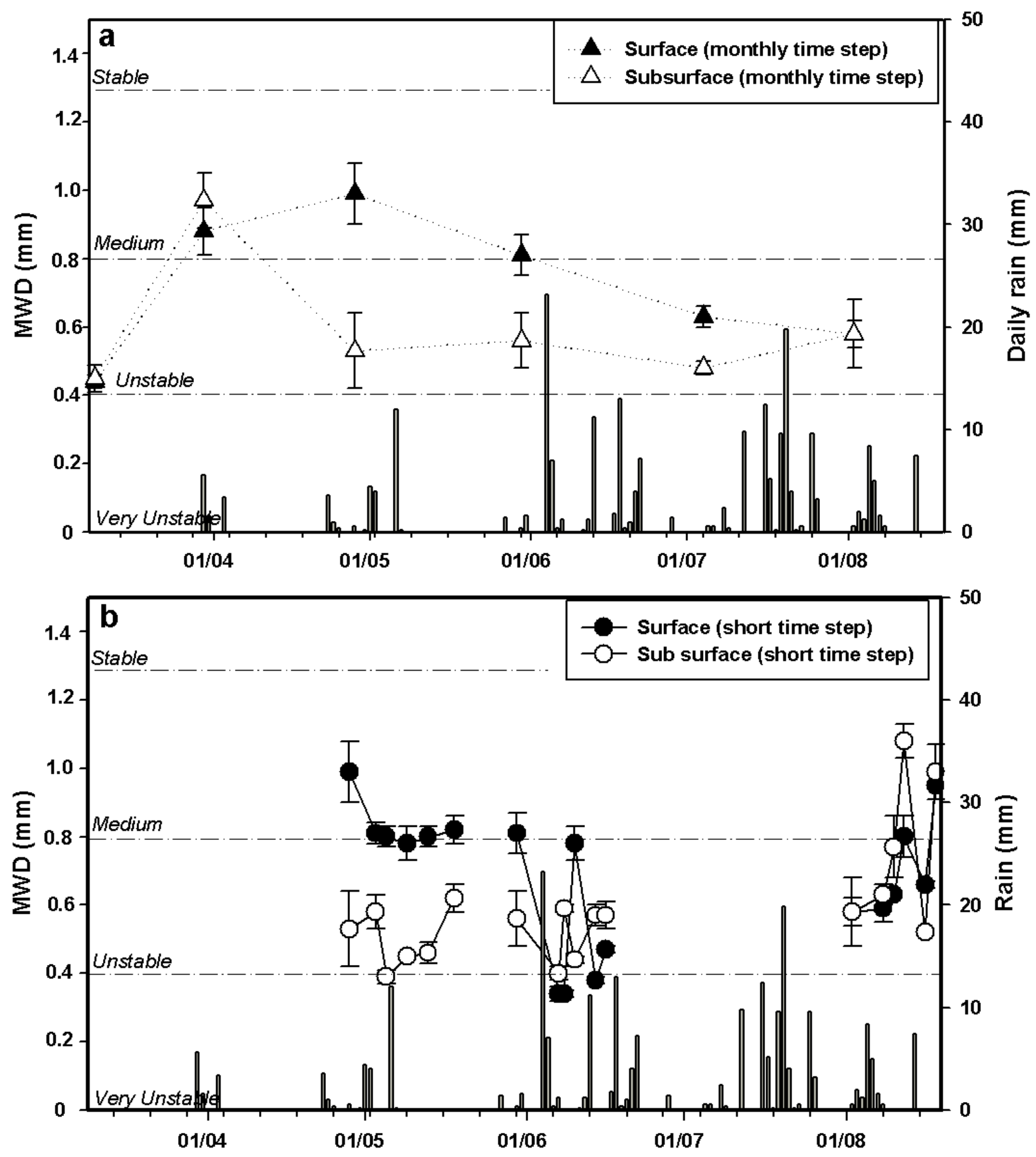

552 Figure 1: Temporal variation of aggregate stability for the slow wetting test of surface and

553 subsurface at montly time step (a) and short time step (b). 
Version définitive du manuscrit publié dans / Final version of the manuscript published in:

Soil Science Society of America Journal, 2014, 78(4), 1168-

http://dx.doi.org/10.2136/sssaj2014.01.0009

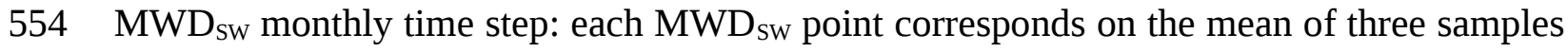

555 located on the same plot (spatial variability) and 3 replicates for each measurements ( $n=9)$.

556 Bars are standard errors.

557 MWD short time step: each MWD corresponds on the mean of three replicates $(n=3)$. Bars

558 are standard error.s

559 Stable, Medium, Unstable, Very unstable, refers to the aggregate stability classes (Le

560 Bissonnais, 1996) 
Version définitive du manuscrit publié dans / Final version of the manuscript published in:
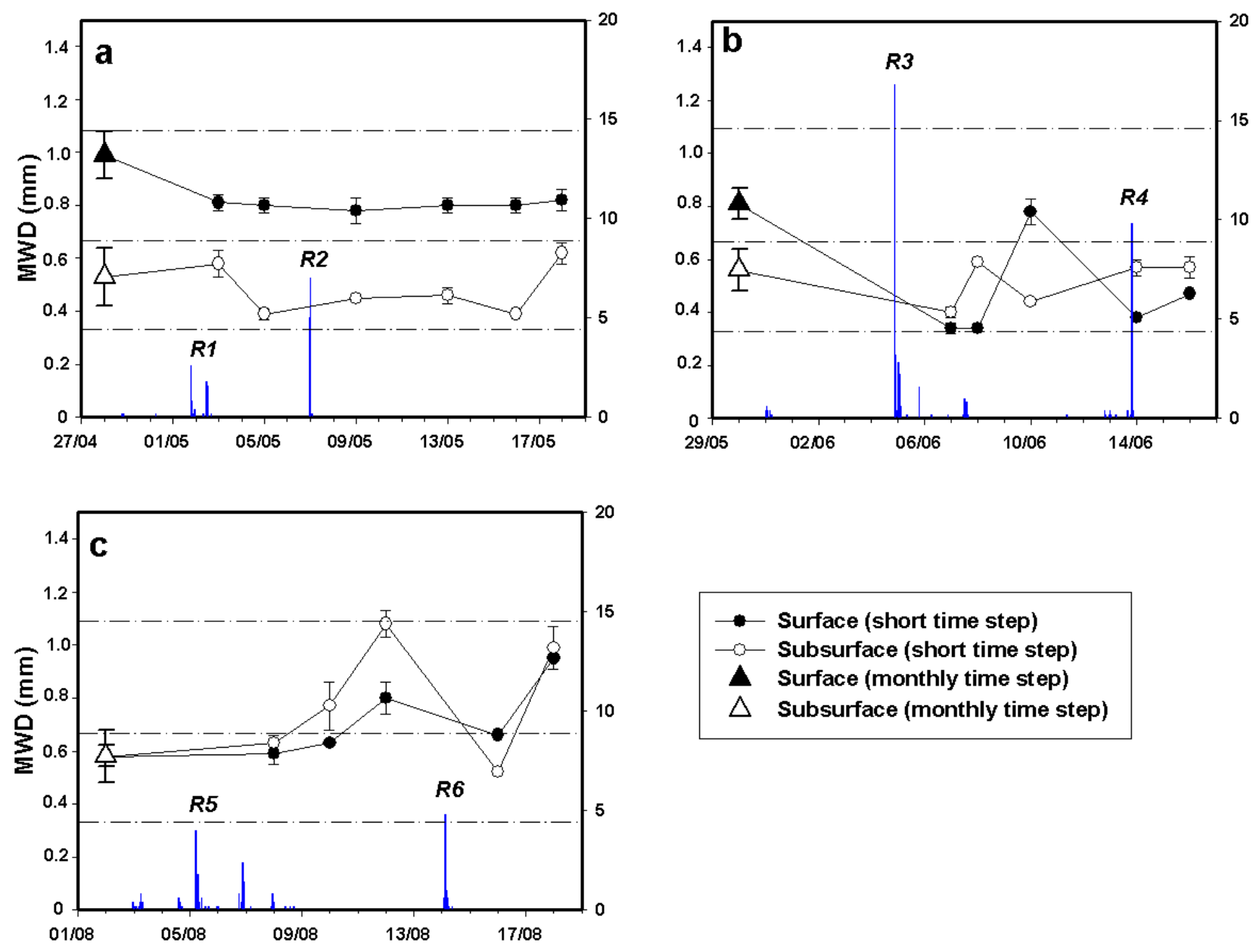

562 Figure 2: Temporal variation of aggregate stability for the slow wetting test at short time

563 step for (a) May , (b) June and (c) August.

564 MWD monthly time step: each MWD corresponds on the mean of three samples located on

565 the same plot (spatial variability) and 3 replicates for each measurements $(n=9)$. Bars are

566 standard errors.

567 MWD short time step: each MWD corresponds on the mean of three replicates $(n=3)$. Bars

568 are standard errors.

569 R1, R2, R3, R4, R5, and R6 refer to the number of the rain event. 
Version définitive du manuscrit publié dans / Final version of the manuscript published in:
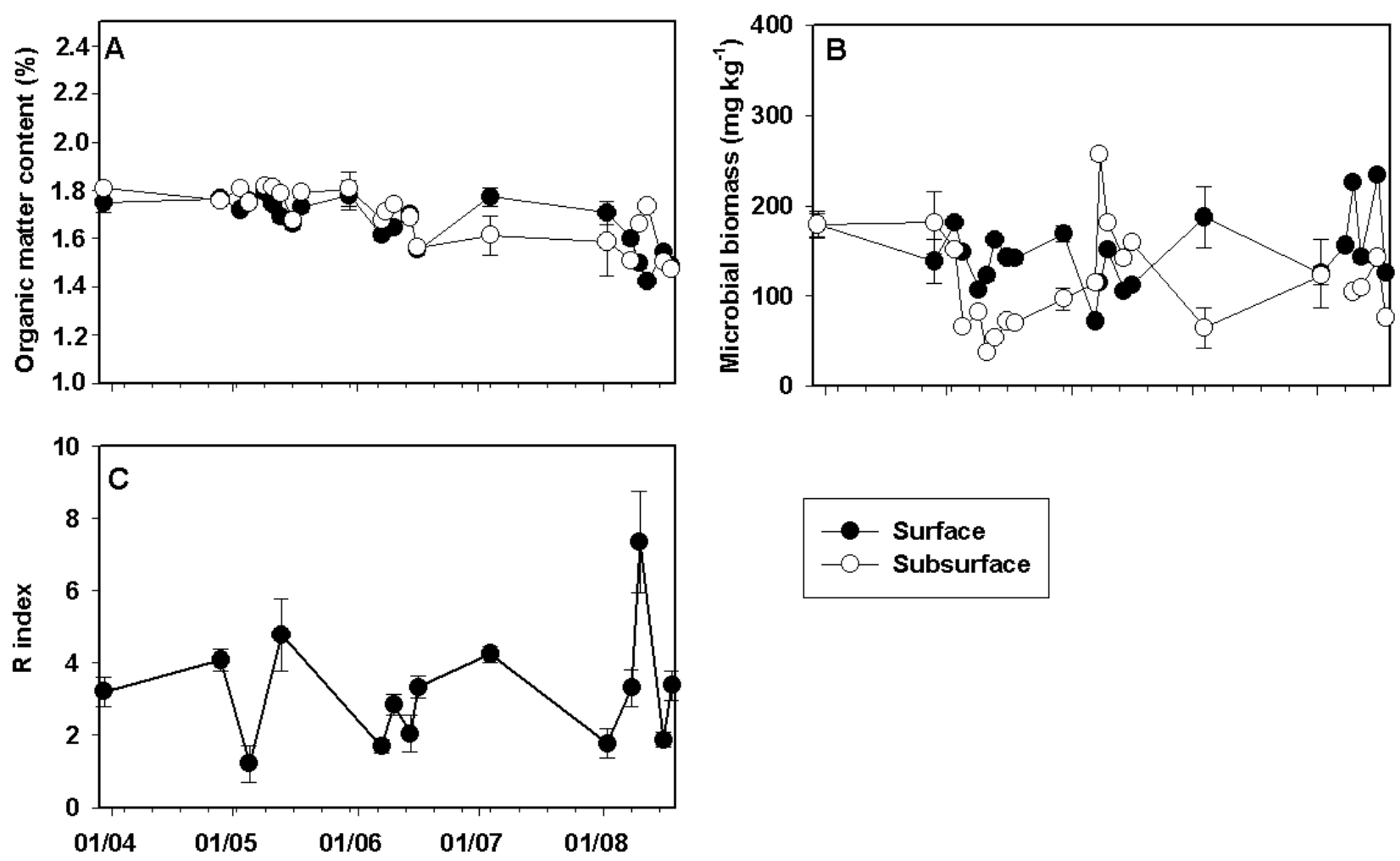

572 Figure 3: Temporal variation in (a) organic matter content, (b) microbial biomass and (c)

573 water repellency.

574 a and b: each point is the mean of three replicates; bars are standard errors.

575 c: each point is the mean of 10 replicates; bars are standard errors. 
Version définitive du manuscrit publié dans / Final version of the manuscript published in:

Soil Science Society of America Journal, 2014, 78(4), 1168-

578 Figure 4: Temporal dynamics of the soil variables; a) Surface soil temperature, b)

579 subsurface soil temperature, c) Volumic soil water content for surface and subsurface.

580 Curves are to the mean of two replicates 